\title{
Flowers of Camellia nitidissima cause growth inhibition, cell-cycle dysregulation and apoptosis in a human esophageal squamous cell carcinoma cell line
}

\author{
LU DAI* , JI-LIN LI* ${ }^{*}$ XIN-QIANG LIANG, LIN LI, YAN FENG, \\ HAI-ZHOU LIU, WEN-ER WEI, SHU-FANG NING and LI-TU ZHANG
}

Research Department, Affiliated Tumor Hospital of Guangxi Medical University, Nanning, Guangxi 530021, P.R. China

Received June 19, 2015; Accepted May 31, 2016

DOI: $10.3892 / \mathrm{mmr} .2016 .5385$

\begin{abstract}
The present study aimed to investigate the chemopreventive effect of Camellia nitidissima flowers water extract (CNFE) on the Eca109 human esophageal squamous cell carcinoma (ESCC) cell line. The antiproliferative effect on Eca109 cells was determined using the trypan blue exclusion assay. The effects of CNFE on apoptosis and cell cycle arrest were investigated by flow cytometry. CNFE inhibited cell growth in both a dose- and time-dependent manner in Eca109 cells. CNFE also caused dose- and time-dependent apoptosis of these cells. Treatment of cells with CNFE resulted in dose-dependent $G_{0} / G_{1}$ phase arrest of the cell cycle. The data demonstrated that CNFE serves antiproliferative effects against human ESCC Eca109 cells by inducing apoptosis and interrupting the cell cycle. These results suggested that CNFE has the potential to be a chemoprotective agent for ESCC.
\end{abstract}

\section{Introduction}

Esophageal cancer (EC) ranks as the eighth most common cancer type, with the sixth highest mortality rate worldwide (1). Esophageal squamous cell carcinoma (ESCC) contributed to $80 \%$ of all EC. Chemoprevention is the chronic administration of a synthetic, natural or biological agent to reduce the concurrency, or delay the occurrence of malignancy, and is a fast evolving field (2). Great efforts have being made to identify effective chemoprotective agents. However, toxicity is always present alongside efficacy in the common

Correspondence to: Dr Li-Tu Zhang, Research Department, Affiliated Tumor Hospital of Guangxi Medical University, 71 Hedi Road, Nanning, Guangxi 530021, P.R. China

E-mail: zhanglitu@gmail.com

*Contributed equally

Key words: chemoprevention, esophageal carcinoma, Camellia nitidissima flowers water extract, Eca109 cells, apoptosis preventive agents, including non-steroidal anti-inflammatory drugs. Therefore, there is a requirement to develop highly efficient chemopreventive agents with fewer side-effects, and natural compounds, including polyphenols and antioxidants, are regarded as important sources for this objective.

Camellia nitidissima Chi $(\mathrm{CN})$, is distributed in a narrow region of Southern China and North Vietnam $(3,4)$. The leaves, flowers and seed oils of $\mathrm{CN}$ are used in foodstuffs and Chinese traditional medicines (5). $\mathrm{CN}$ has several similar constituents as other Camellia sinensis species, including green tea, however, it also has some unique phytochemicals as well $(5,6)$. Ethanol extracts of the seeds of $\mathrm{CN}$ exhibit cytotoxicity against human lymphoma cells, and cervical and prostate cancer cells (7). The amount of bioactive components in $\mathrm{CN}$ flowers is reported to be higher compared with that in the leaves (6). A previous study reported that flavonoid glycoside extracted from the flowers of $\mathrm{CN}$ slowed down the proliferation of human lymphoma U937 cells (8). The toxicity of $\mathrm{CN}$ is quite low. A previous study by Peng et al recently showed that fresh $\mathrm{CN}$ leaf water extracts caused no acute, subacute or genetic hazards in the mouse acute oral toxicity test, 90-day feeding in male Wistar rat, Ames test, mouse teratospermia test and mice sperm abnormality test (9). Another previous study showed that the lethal dose, $50 \%\left(\mathrm{LD}_{50}\right)$ on mice oral toxicity test was up to $106.7 \mathrm{~g}$ crude $\mathrm{drug} / \mathrm{kg}$ (10).

However, the effect of $\mathrm{CN}$ flower extracts on the prevention of ESCC remains to be studied. Drinking is the most common way for humans to consume teas. Therefore, water extracts of the $\mathrm{CN}$ flower represents the components that would be consumed by humans through daily tea drinking.

In the present study, the $\mathrm{CN}$ flower water extract (CNFE) was used to investigate possible chemopreventative effects of $\mathrm{CN}$ on an ESCC cell line, Eca109. The cell viability change and apoptosis induced by CNFE were first evaluated, and the effect of CNFE on the cell cycle was further analyzed using flow cytometry.

\section{Materials and methods}

Preparation of CNFE. Dry CN flowers were provided by Guangxi Nongyi Organic Agriculture Company (Guangxi, China). A total of $10 \mathrm{~g}$ dry $\mathrm{CN}$ flowers were steeped 
in $100 \mathrm{ml}$ near boiling double distilled $\mathrm{H}_{2} \mathrm{O}$ for $1 \mathrm{~h}$. The infusion was filtered twice through a $0.45 \mu \mathrm{m}$ polyvinylidene difluoride (PVDF) filter disk (EMD Millipore, Billerica, MA, USA) and vacuum freeze dried at $-80^{\circ} \mathrm{C}$ to produce a powdered crude extract, which was stored at $-20^{\circ} \mathrm{C}$ until use. Prior to the experiments, the powdered crude extract was dissolved in Dulbecco's modified Eagle's medium (DMEM; Thermo Fisher Scientific, Inc., Waltham, MA, USA) at a concentration of $100 \mathrm{mg} / \mathrm{ml}$ and filtered twice through a $0.22 \mu \mathrm{m}$ PVDF filter disk (EMD Millipore).

Cell culture. The ESCC cell line, Eca109, was purchased from Shanghai Institute for Biological Sciences, Chinese Academy of Sciences (Shanghai, China). The Eca109 cells were cultured in DMEM, supplemented with $10 \%$ fetal bovine serum (Thermo Fisher Scientific, Inc.) and incubated at $37^{\circ} \mathrm{C}$ in an atmosphere of $5 \% \mathrm{CO}_{2}$.

Trypan blue exclusion assay. Eca109 cells were cultured in 6 -well plates $\left(8 \times 10^{5}\right.$ cells/well) for $24 \mathrm{~h}$. When the cells reached $\sim 70 \%$ confluence, they were treated with CNFE at five different concentrations (100, 200, 300, 400 and $500 \mu \mathrm{g} / \mathrm{ml})$ for 24,48 or $72 \mathrm{~h}$. Then the cells were trypsinized and mixed $1: 1$ with $0.4 \%$ trypan blue solution for 2-3 min. The cells were counted on a hemocytometer using an inverted phase contrast microscope. Viable cells exclude trypan blue, while dead cells stain blue due to trypan blue uptake. The ratio of the numbers of dead cells divided by the total number of cells is calculated as the percentage of cell death. At each time point, the effect of CNFE was compared with the non-treated control.

Quantification of apoptosis byflow cytometry. The Eca109 cells were plated at a density of $4 \times 10^{5}$ cells in 6-well plates and treated with CNFE at 100, 200, 300, 400 and $500 \mu \mathrm{g} / \mathrm{ml}$. The cells were harvested at the indicated time points, washed twice with cold phosphate-buffered saline, centrifuged for $5 \mathrm{~min}$ at $300 \mathrm{x} \mathrm{g}$ at room temperature. The cells were subsequently stained with Annexin $\mathrm{V}$ and propidium iodide (PI) using the fluorescein isothiocyanate (FITC)-Annexin V Apoptosis Detection Kit I (BD Bioscience, Franklin Lakes, NJ, USA). Briefly, the cells were incubated at room temperature with $3 \mu \mathrm{l}$ FITC-Annexin V staining solution for $10 \mathrm{~min}$ and $2 \mu \mathrm{l} \mathrm{PI}$ staining solution for $5 \mathrm{~min}$ in sequence. A total of $100 \mu \mathrm{l} 1 \mathrm{X}$ binding buffer was added at room temperature in the dark and the labeled cells were subsequently analyzed by flow cytometry.

DNA cell cycle analysis. The Eca109 cells (70\% confluence) were serum starved for $36 \mathrm{~h}$ to synchronize in $\mathrm{G}_{0}$ phase. They were treated with CNFE at 100, 200, 300, 400 and 50 $0 \mu \mathrm{g} / \mathrm{ml}$ in complete culture medium for $24 \mathrm{~h}$. The cells were subsequently trypsinized, washed twice with buffer solution (BD Biosciences) and centrifuged for $5 \mathrm{~min}$ at $300 \mathrm{x} \mathrm{g}$ at room temperature each time. The pellet was re-suspended in buffer and frozen at $-80^{\circ} \mathrm{C}$ until analysis. The frozen samples were thawed rapidly in a water-bath at $37^{\circ} \mathrm{C}$. The cells were centrifuged for $5 \mathrm{~min}$ at $400 \mathrm{x} \mathrm{g}$ at room temperature and stained with the Cycle TEST ${ }^{\mathrm{TM}}$ PLUS DNA Reagent kit (BD Biosciences), according to the manufacturer's instructions. The labeled cells were subsequently analyzed by flow cytometry.
Statistical analysis. The probit regression model was applied to estimate the half-maximal inhibitory concentration $\left(\mathrm{IC}_{50}\right)$ values of CNFE on Eca109 cells. $\chi^{2}$ was applied to determine the event probability of the cytostatic or cytotoxic effect of CNFE, and to assess the effects of CNFE on the induction of apoptosis and cell-cycle perturbation. All statistical analyses were performed using SPSS 16.0 (SPSS, Inc., Chicago, IL, USA). $\mathrm{P}<0.05$ was considered to indicate a statistically significant difference.

\section{Results}

CNFE inhibited the growth of Ecal09 cells. Firstly, the present study investigated the effects of CNFE on the viability of Eca109 cells by trypan blue exclusion assay (Fig. 1). As shown in Fig. 1, the percentage of dead cells increased both in a time- and dose-dependent manner. Compared with the non-treated control, the percentage of dead cells when Eca109 cells were treated with $300 \mu \mathrm{g} / \mathrm{ml}$ of CNFE for $24 \mathrm{~h}$ was significantly increased (34.43 vs. $6.43 \%$ ). The cell death of Eca109 cells increased gradually when treated with CNFE at 300,400 and $500 \mu \mathrm{g} / \mathrm{ml}$ for $24 \mathrm{~h}(\mathrm{P}<0.001$, compared with the control; Fig. 1). The percentage of dead cells when Eca109 cells were treated with CNFE (300, 400 or $500 \mu \mathrm{g} / \mathrm{ml})$ for $24 \mathrm{~h}$ was $34.42,37.30$ and $39.43 \%$, respectively. Treatment with $200 \mu \mathrm{g} / \mathrm{ml} \mathrm{CNFE}$ for 48 or $72 \mathrm{~h}$ significantly reduced the cell viability $(\mathrm{P}<0.001$, compared with control; Fig. 1$)$. The antiproliferative effect of CNFE was also time-dependent. The $\mathrm{IC}_{50}$ of CNFE on Eca109 cells, calculated accordingly at 24,48 and $72 \mathrm{~h}$, was 513.64, 326.88 and $217.31 \mu \mathrm{g} / \mathrm{ml}$, respectively (Fig. 1).

CNFE induced apoptosis of Ecal09 cells. The apoptosis of Eca109 cells was further analyzed by flow cytometry using FITC-Annexin V and PI (Fig. 2).In control cells, the percentage of early apoptotic cells was $3.01 \%$ and the percentage of late apoptotic/dead cells was $5.91 \%$ (Fig. 2). Following incubation with $100 \mu \mathrm{g} / \mathrm{ml} \mathrm{CNFE}$ for $48 \mathrm{~h}$, the percentages of early apoptotic cells and late apoptotic cells increased to 14.16 and $7.27 \%$, respectively $(\mathrm{P}<0.01$; Fig. 2$)$. The apoptosis of Eca109 cells after treatment with 100-500 $\mu \mathrm{g} / \mathrm{ml} \mathrm{CNFE}$ for $48 \mathrm{~h}$ was significantly increased in a dose-dependent manner (Fig. 2). The percentage of apoptotic cells (early and late apoptosis in total) gradually increased as the incubating time was extended. The percentage of apoptotic Eca109 cells following treatment with $300 \mu \mathrm{g} / \mathrm{ml}$ CNFE for 24,48 and $72 \mathrm{~h}$ were $16.55,25.14$ and $30.72 \%$ respectively, each significantly increased compared with that of the control cells $(9.09,8.92$ and $15.07 \%$, respectively; $\mathrm{P}<0.001$; Fig. 3).

CNFE resulted in $G_{0} / G_{1}$ arrest in Ecal09 cells. To study whether CNFE can interrupt the cell cycle, flow cytometric analysis with PI staining was used to analyze the distribution of the cell cycle. After treatment with CNFE at $200 \mu \mathrm{g} / \mathrm{ml}$ for $24 \mathrm{~h}$, the number of cells in $\mathrm{G}_{0} / \mathrm{G}_{1}$ phase was $61.67 \%$, which was significantly more compared with the $51.66 \%$ observed in control cells $(\mathrm{P}<0.001$; Fig. 4). The $\mathrm{S}$ phase cell population and $\mathrm{G}_{2} / \mathrm{M}$ phase cell population were significantly reduced to 34.30 and $4.04 \%$, compared with the 36.44 and $11.91 \%$ 


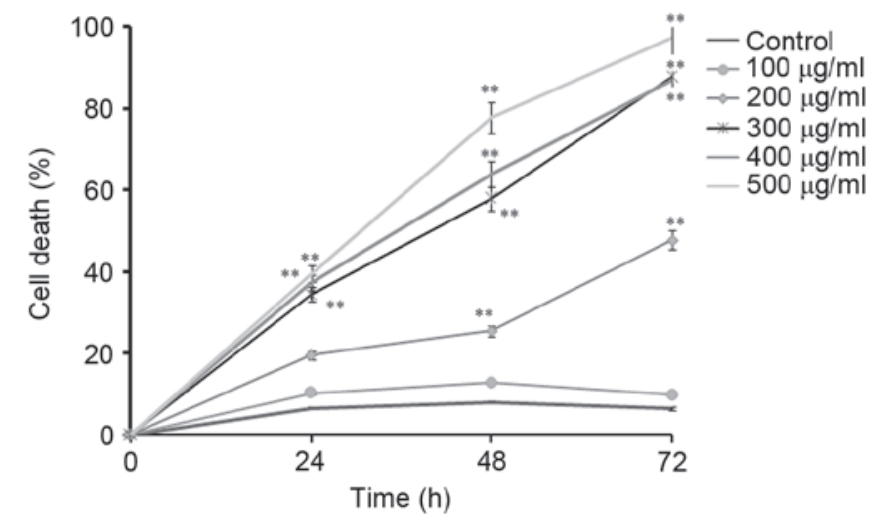

Figure 1. Viability of Eca109 cells following treatment with CNFE. Eca109 cells were exposed to different concentrations of CNFE for up to $72 \mathrm{~h}$. The percentage of dead cells was determined using a trypan blue exclusion assay. Each experiment was performed independently three times. The data are presented as the mean \pm standard deviation ${ }^{* * *} \mathrm{P}<0.001$, compared with the control at 24, 48 and $72 \mathrm{~h}$. CNFE, Camellia nitidissima flowers water extract; h, hours.
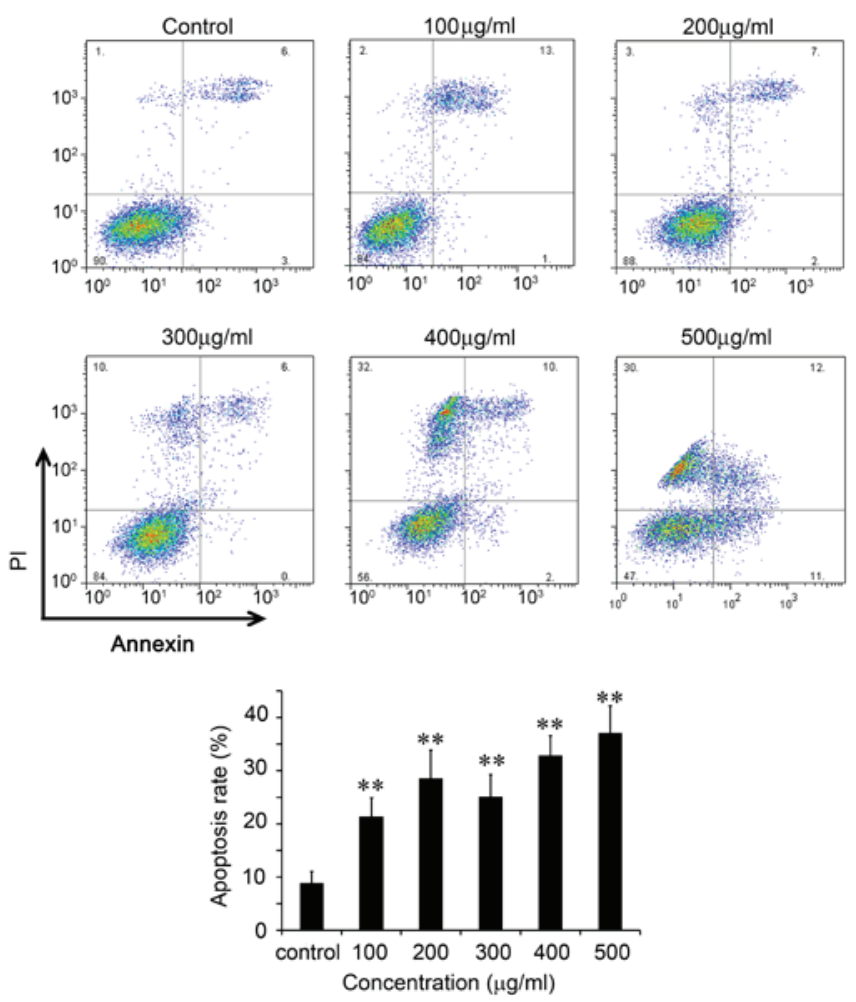

Figure 2. Apoptosis of Eca109 cells induced by CNFE at different concentrations. Eca109 cells were treated with different concentrations of CNFE for $48 \mathrm{~h}$, labeled with fluorescein isothiocyanate-Annexin V and PI, and analyzed by flow cytometry. Data shown are from a representative experiment which was repeated three times. ${ }^{* *} \mathrm{P}<0.01$ vs. the control. CNFE, Camellia nitidissima flowers water extract; PI, propidium iodide.

observed in control cells ( $\mathrm{P}<0.001$; Fig. 4), respectively. The $\mathrm{G}_{0} / \mathrm{G}_{1}$ arrest effect of CNFE on Eca109 cells in $\mathrm{G}_{0} / \mathrm{G}_{1}$ phase was dose-dependent $(\mathrm{P}<0.001$; Fig. 4). However, this effect appeared not to be time-dependent. Even when the incubation time was extended to $48 \mathrm{~h}$, the cell cycle distribution revealed no significant change when compared with that at 12 or $36 \mathrm{~h}$ (Fig. 5).
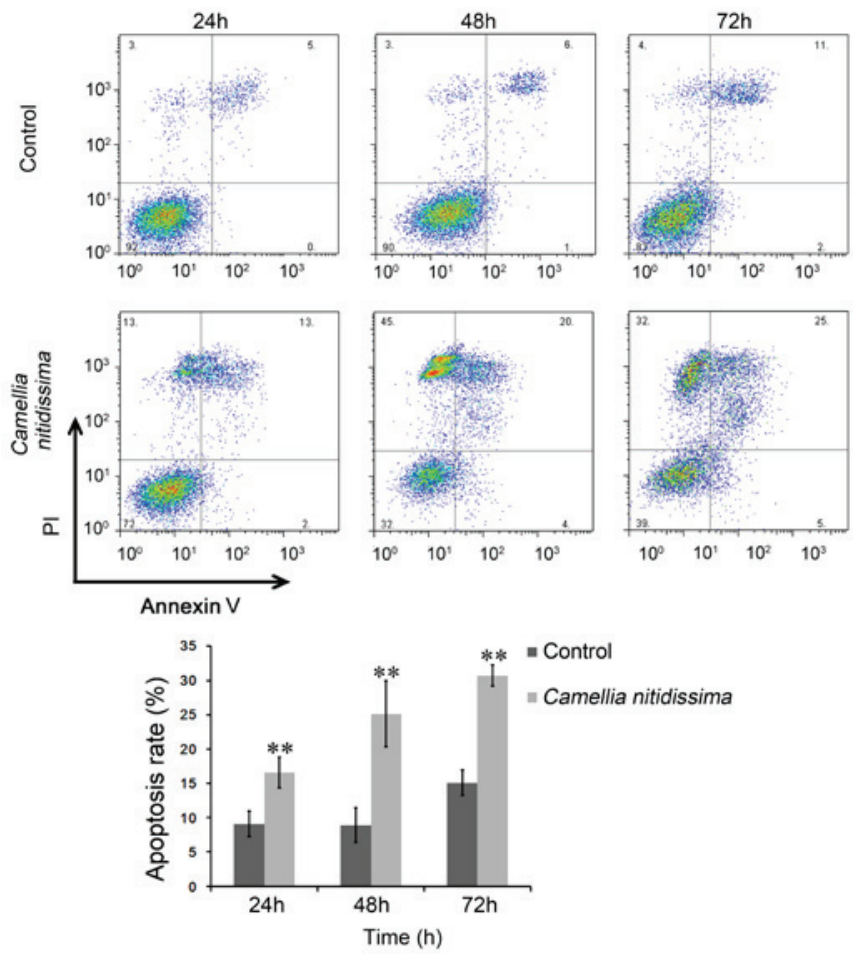

Figure 3. Apoptosis of Eca109 cells induced by CNFE at different time points. Eca109 cells were treated with vehicle or CNFE $(300 \mu \mathrm{g} / \mathrm{ml})$ for 24, 48 and $72 \mathrm{~h}$, labeled with fluorescein isothiocyanate-Annexin $\mathrm{V}$ and PI, and analyzed by flow cytometry. Representative data are from three independent experiments. ${ }^{* *} \mathrm{P}<0.01$ vs. the control. CNFE, Camellia nitidissima flowers water extract; PI, propidium iodide; h, hours.

\section{Discussion}

As a part of the ongoing program of investigating the $\mathrm{CN}$ flower in relation to cancer chemoprevention, the present study evaluated the cancer preventive effect of CNFE on the human ESCC cell line, Eca109. It was demonstrated that CNFE was able to reduce Eca109 viability both in a time- and dose-dependent manner. CNFE induced the apoptosis of Eca109 cells and caused $\mathrm{G}_{0} / \mathrm{G}_{1}$ arrest.

Similar to other C. sinensis species (e.g. green tea), CN is rich in antioxidants, including numerous polyphenols such as gallocatechin, epicatechin, epigallocatechin-3-gallate and gallocatechin gallate $(4,6)$. Only a few previous studies have investigated the possibility of $\mathrm{CN}$ extracts in preventing cancer $(4,6,7)$. Water extracts of $\mathrm{CN}$ leaf reduce the viability of breast cancer cells (7), and ethanol extracts from the flowers of $\mathrm{CN}$ inhibit proliferation and induce apoptosis in human lymphoma cells (8). CN flowers contain more phytochemicals compared with those in the leaves and these include flavonoids, tea polyphenols and saponin (6). Peng et al (8) and his colleagues reported that a unique acylated flavonoid glycoside in the ethanol extract of $\mathrm{CN}$ flowers induced the apoptosis of human lymphoma cells (8). These bioactive components may serve a role in the anticancer ability of CNFE. Previous studies have confirmed that the water extract of $\mathrm{CN}$ leaves and flowers can inhibit the proliferation of hepatoma cells and the diethylnitrosamine-induced precancerous lesions in rat liver $(11,12)$. In the present study, CNFE resulted in loss of Eca109 cell viability in a dose- and time-dependent manner, 
A

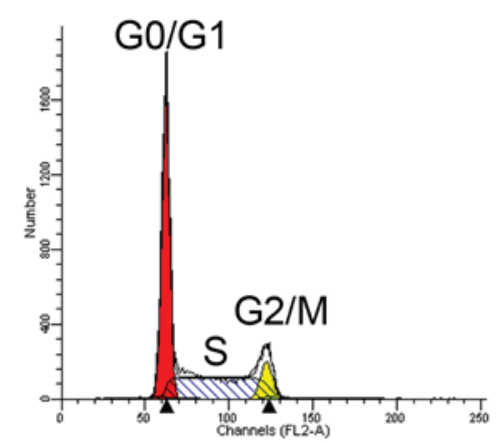

$300 \mu \mathrm{g} / \mathrm{ml}$

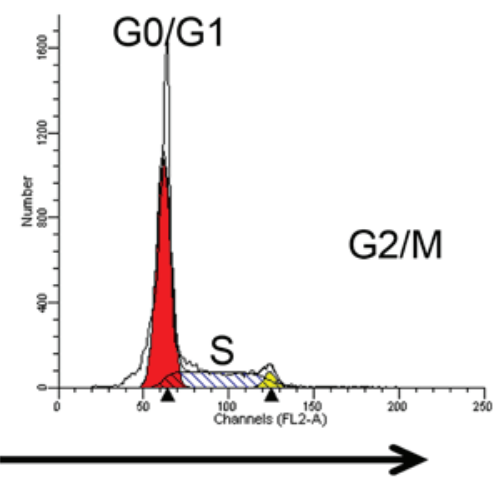

DNA Content
$100 \mu \mathrm{g} / \mathrm{ml}$

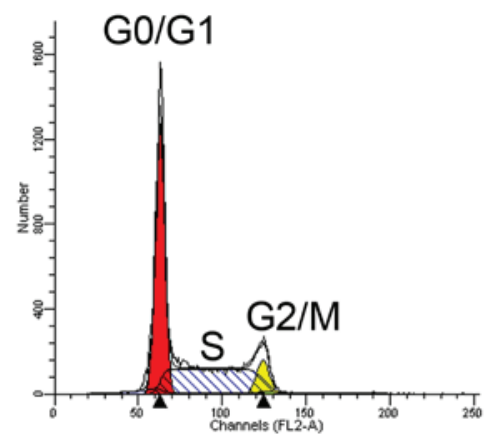

$400 \mu \mathrm{g} / \mathrm{ml}$

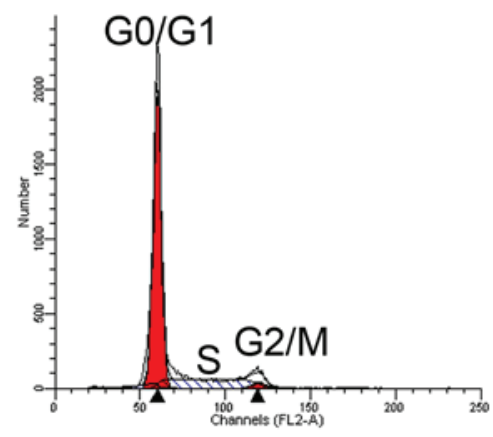

$200 \mu \mathrm{g} / \mathrm{ml}$
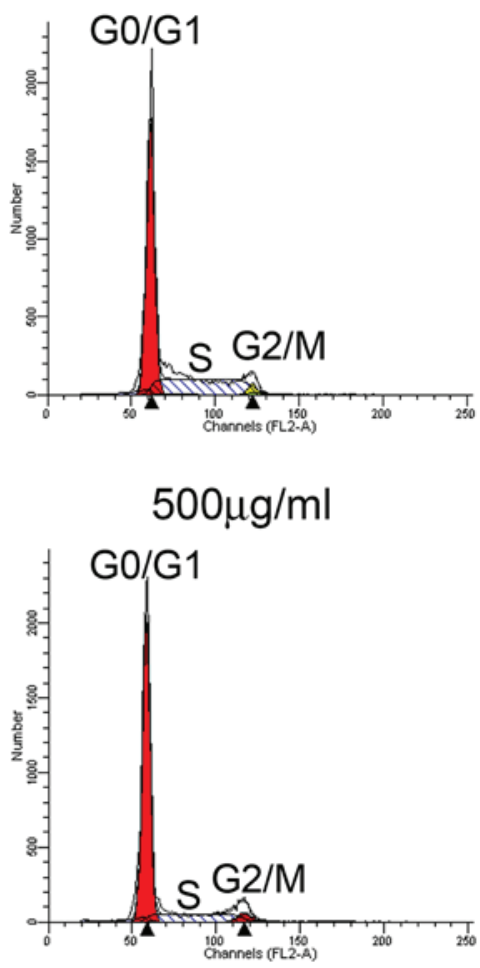

B

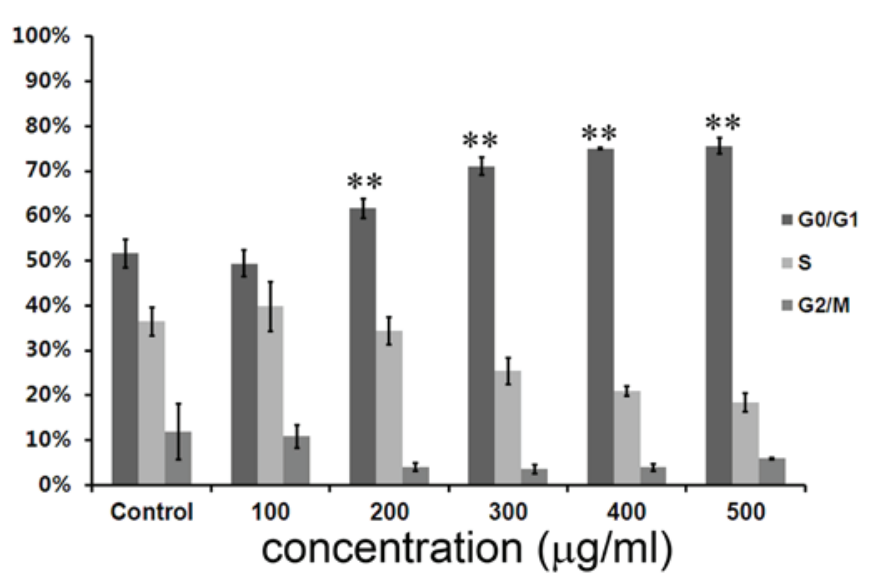

Figure 4. Effect of CNFE on cell-cycle perturbation at different concentrations. (A) Eca109 cells were treated with vehicle or different concentrations of CNFE for $24 \mathrm{~h}$, labeled with propidium iodide and analyzed by flow cytometry. The first peak represents $\mathrm{G}_{0} / \mathrm{G}_{1}$ phase cell population and the second peak represents $\mathrm{G}_{2} / \mathrm{M}$ phase cell population. The data shown are from a representative experiment, which was repeated three times with similar results. (B) The histograms were obtained by PI staining $\left({ }^{* * *} \mathrm{P}<0.01\right)$. CNFE, Camellia nitidissima flowers water extract.

and also induced apoptosis in a dose- and time-dependent manner.

Cells can be arrested in G1, S and G2/M phases of the cell cycle to prevent replication of damaged DNA or to prevent aberrant mitosis. The present study also confirmed that CNFE was able to arrest Eca109 cells in $\mathrm{G}_{0} / \mathrm{G}_{1}$ phase, dose-dependently. It was similar to that of green tea and tea polyphenols, which most likely arrest cells in $\mathrm{G}_{0} / \mathrm{G}_{1}$ phase (13).

However, the cycle arrest and the apoptosis were affected differently in a time-dependent manner. When the Eca109 cells were treated with CNFE at $200 \mu \mathrm{g} / \mathrm{ml}$, the apoptosis rate increased sharply from 24 to $72 \mathrm{~h}$, however, the percentage of cells arrested in $G_{0} / G_{1}$ phase appeared to remain the same. It is possible that the cell cycle arrest is not the predominant cause of the CNFE-induced the Eca109 cell death. A previous study demonstrated that compounds in $\mathrm{CN}$ flower EtOAc-soluble fraction can activate caspase 3 (8). Therefore, CNFE may possibly cause cell death by directly activating the caspase pathway; however, this requires further investigation.

The CNFE exerted its effect by inhibiting cell proliferation and inducing apoptosis; however, its role in chemoprevention on ESCC and its targets were predominantly unknown. Further studies on the underlying mechanisms may assist with highlighting the chemopreventive potential of this rare plant. 
A
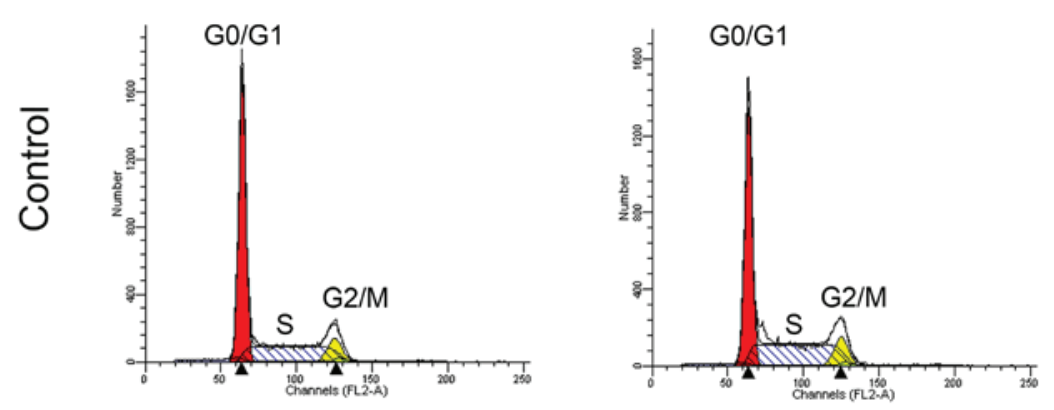

$48 \mathrm{~h}$
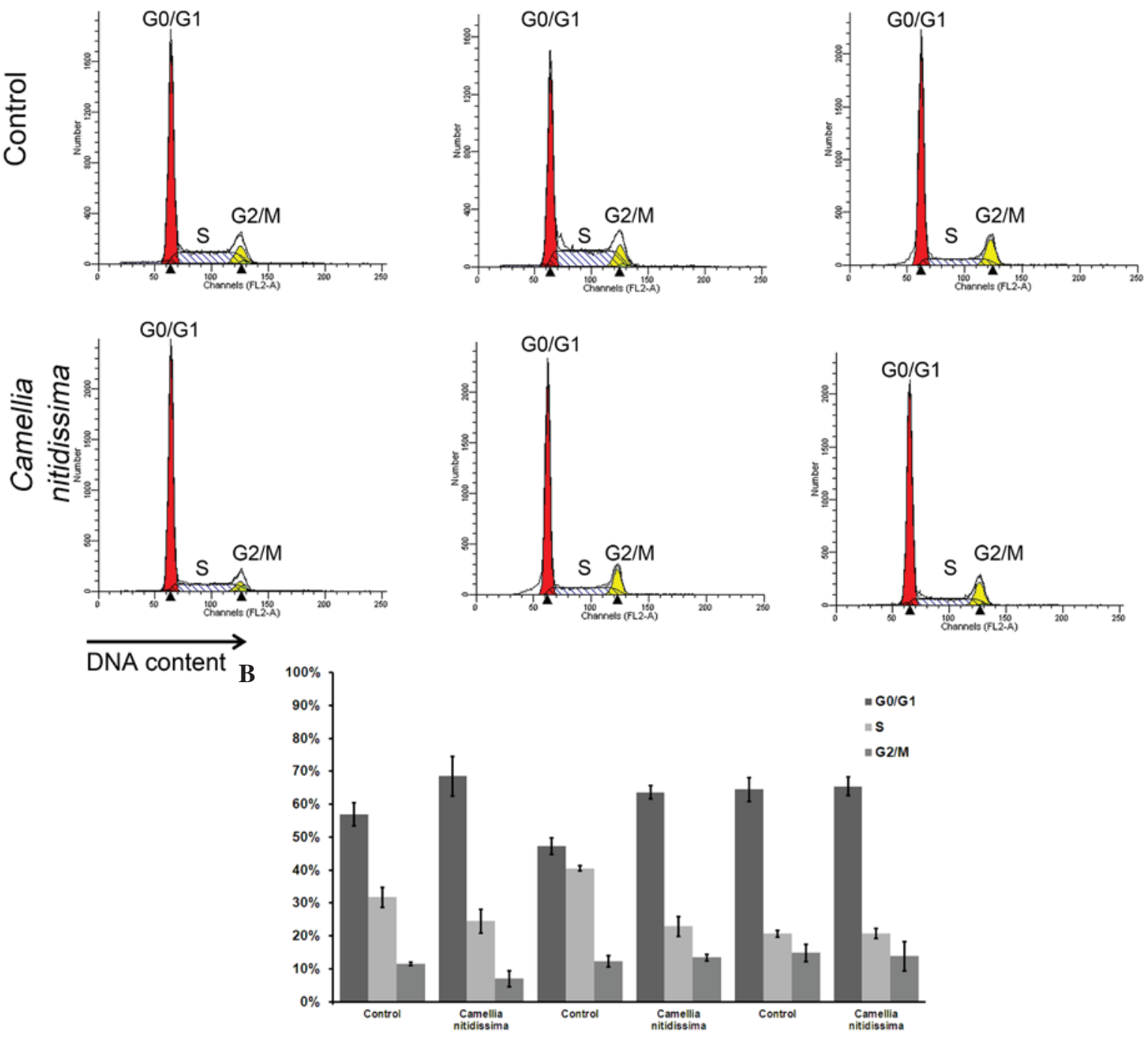

Figure 5. Effect of CNFE on cell-cycle perturbation at different time points. (A) Eca109 cells were treated with vehicle or CNFE (200 $\mu \mathrm{g} / \mathrm{ml})$ for 12,36 and $48 \mathrm{~h}$, labeled with PI and analyzed by flow cytometry. The data shown are from a representative experiment repeated three times with similar results. (B) The histograms were obtained by PI staining. CNFE, Camellia nitidissima flowers water extract; PI, propidium iodide.

Furthermore, as CNFE contains a variety of water-soluble constituents, the individual constituent that is the most important in preventing cancer remains unknown. Future studies must focus on the most effective antioxidant fractions and their functions in vivo, and this may assist in developing effective chemoprevention agents from $\mathrm{CN}$ extracts.

In conclusion, the present study has demonstrated that CNFE can reduce the viability of Eca109 cells by affecting the cell cycle and by inducing apoptosis in vitro. The results of the present study suggested that CNFE or some of its constituents may be potential chemopreventive agents for ESCC in the future.

\section{Acknowledgements}

The authors would like to thank Dr Dev Sooranna (Imperial College, London, UK) for his assistance in editing the manuscript.
The present study was supported by grants from the Key Research Projects of Guangxi Health Department (no. Z2011083), the Guangxi Graduate Education Innovation Projects 2011 (no. 2011105981002M179) and the Administration of Traditional Chinese Medicine in Guangxi Research projects (no. GZZC1144).

\section{References}

1. Jemal A, Bray F, Center MM, Ferlay J, Ward E and Forman D: Global cancer statistics. CA Cancer J Clin 61: 69-90, 2012.

2. Steward WP and Brown K: Cancer chemoprevention: A rapidly evolving field. Br J Cancer 109: 1-7, 2013.

3. Tang S, Bin X, Wang L and Zhong Y: Genetic diversity and population structure of yellow camellia (Camellia nitidissima) in China as revealed by RAPD and AFLP markers. Biochem Genet 44: 449-461, 2006.

4. Qin XL, Shi YC, Li CZ, Wei X, Huang RS, Kong DX and Huang SS: Study on camellia sect. Chrysantha Chang species identification by FTIR technology. Guang Pu Xue Yu Guang Pu Fen Xi 32: 2685-2689, 2012 (In Chinese). 
5. Huang Y, Wen Y, Chen Y, et al: Extraction technology and dynamic change of flavonoids in Camellia nitidissima leaves. Shipin Kexue 30: 72-75, 2009.

6. Lin H, Qin X, Zeng Q, Yang J and Zhong J: Analysis on chemical and bioactive components in flower of Camellia chrysantha $(\mathrm{Hu})$ Tuyama. Food Science and Technology 35: 88-91, 2010.

7. Han LC, Shi LY, Yu DY, et al: Inhibitive effect of seeds of camellia chrysantha $(\mathrm{Hu})$ tuyama on gonadal hormones dependent tumour in vitro. Lishizhen Med Mat Med Res 20: 3146, 2009.

8. Peng X, Yu DY, Feng BM, Wang YQ and Shi LY: A new acylated flavonoid glycoside from the flowers of Camellia nitidissima and its effect on the induction of apoptosis in human lymphoma U937 cells. J Asian Nat Prod Res 14: 799-804, 2012.

9. Peng L, Zhang P, Bing L, Huang CP, Yao SY and HY Q Toxicological safety studies of Camellia nitidissima chi fresh leaf. J Toxicol February 25: 72-74, 2011.
10. Xia X, Huang JJ, Wang ZP, Wang Q and WG P: The hypoglycemic effects and acute toxicity studies of nitidissima chi. Arch Iran med lishizhen medicine and materia medica research 1281-1282, 2013

11. Duan X, Tang X, Su J, et al: Study on inhibition of C. chrysantha on DEN induction of murine liver cancer. Journal of Medical Research 35: 14-19, 2006.

12. Li C, Duan X, Su J, et al: Impact of leaves and flowers of camellia chrysantha $(\mathrm{Hu})$ tuyama of different concentrations on Diethylnitrosaminal-induced precancerous lision to liver of rat and hepatoma cells BEL-7404. Journal of Guangxi Medical University 24: 660-663, 2007.

13. Ahmad N, Feyes DK, Nieminen AL, Agarwal R and Mukhtar H: Green tea constituent epigallocatechin-3-gallate and induction of apoptosis and cell cycle arrest in human carcinoma cells. J Natl Cancer Inst 89: 1881-1886, 1997. 